\title{
İş Hukuku Sözleşmelerinde Şekle Uymamanın Hüküm ve Sonuçları*
}

\author{
According to Labour Law Agreement The Consequence and Provision of Disobey \\ Osman Çiftçi a ${ }^{\text {,** }}$ \\ a İstanbul Aydın Üniversitesi,Hukuk Fakültesi, Hukuk Bölümü,34290,K. Çekmece / İstanbul. \\ ORCID: 0000-0003-1384-4598
}

\section{MAKALE BİLGISII}

Makale Geçmişi:

Başvuru tarihi: 28 Şubat 2019

Düzeltme tarihi: 17 Nisan 2019

Kabul tarihi: 26 Nisan 2019

Anahtar Kelimeler:

Şekil Şartı

Sözleșme

Sözleşme Özgürlüğü

İş sözleşmesi
ÖZ

Türk Borçlar Kanununun 12. maddesinde, sözleşmelerin geçerliliğinin kanunda aksi öngörülmedikçe hiçbir şekil şartına bağlı olmadığı belirtilmiştir. Ayrıca maddenin devamına göre ise kanunda öngörülen şekle uyulmadan yapılan sözleşmelerin hüküm doğurmayacağ belirtildiğinden bu şekle uyulmadan yapılan sözleşmelere, hükümsüzlük (geçersizlik) yaptırımı uygulanmaktadır. "Şekle Uymamanın Hüküm ve Sonuçları" başlıklı bu çalışmada iş sözleşmesinin kuruluşunda şekil ile geçerlilik şekli bakımından ve ispat şartı şekli bakımından şekle uymamanın hüküm ve sonuçları değerlendirilmiştir. Bu çalışmada ayrıca doktrinde TBK'nun 12. maddesinde sözleşmelerin kanunda öngörülen şekle uyulmaması durumunda geçersizliğin kesin hükümsüzlük olduğunu ifade eden görüş ile birlikte zamanda doktrinde yer alan butlan, kendine özgü geçersizlik, yokluk, iptal edilebilirlik ve kesin hükümsüzlük görüşleri de değerlendirilmiştir.

\section{ARTICLE INFO}

Article history:

Received 28 February 2019

Received in revised form 17 April 2019

Accepted 26 April 2019

\section{Keywords:}

Form Laws,

Freedom of Contrats

Contarct

Labour Contract

\section{A B S T R A C T}

At the 12nd rule Turkish law of obligations, validity of contracts law save as otherwise provided under no circumstances within the same entry, in the law for the contracts requirments are needed also there is no validity of contract which is not same as others. İn addition to this according to this article continuous there is dissatisfaction will be applied " the consequence of non compliance" in this article there is evaluated the result of failure to comply with results.Also in this article in the case of the breaking of the rule doctrine invalidity disappearance, amulability and also utilized opinion are evaluated.

\section{Giriş}

Hukuki işlemlerde tarafların irade beyanlarının dişa vurulması olarak karşımıza çıkan şekil kavramının varlığ çok eski tarihlere dayanmaktadır. Eski hukuk sistemlerinde taraf iradelerinin ayrılmaz bir parçası olan şekil kuralları günümüz modern hukuk sistemlerinde iradenin varlığının dışında sadece iradenin dişa vurumu esnasındaki görünümünden ibarettir. İş hukukunda şekle ilişkin olarak düzenlenen genel prensipler Türk Borçlar Kanununda düzenlenmiştir. $\mathrm{Bu}$ bağlamda iş sözleşmelerinin kuruluşunda genel esas şekil serbestisi olup ayrica Türk Hukuk Sisteminde sözleşme özgürlüğü Borçlar Hukukunun da en temel prensiplerinden biridir (Oğuzman \& Öz 2013). $\mathrm{Bu}$ prensip uyarınca iş sözleşmeleri herhangi özel bir şekle tâbi olmaksızın sözleşmeyi yapan tarafların arzuları doğrultusunda serbestçe kurulabilmektedir. İşçi ile işveren iş sözleşmesini birbirlerine uygun iradelerini yazılı, sözlü ve

* Bu çalışma yazarın 2019 yılında Prof. Dr. Fahrettin KORKMAZ danışmanlığında İstanbul Aydın Üniversitesi Sosyal Bilimler Enstitüsü Özel Hukuk Anabilim Dalı'nda yürüttüğü “İş Sözleşmesinde Şekil Serbestisi” başlıklı yüksek lisans tezinden türetilmiştir.

** Sorumlu yazar/Corresponding author

e-posta: ciftciosmannn@gmail.com 
hatta örtülü bir biçimde ifade ederek sözleşmesel ilişki içerisine girebilirler (Oğuzman \& Öz 2013). Bu nedenle işçinin ancak ücret karşılığı yapılabilecek nitelikteki işi belirli bir zaman dilimi içerisinde yapmaya başlaması, işverenin ise bu edimi kabul etmesi ile birlikte teknik anlamda bir iş sözleşmesi kurulmuş olacaktır (Süzek, 2016) Ancak, Borçlar Kanununda olduğu gibi bu genel kuralın istisnalar1 da mevcuttur.

Kanun koyucu bazı iş sözleşmelerinde yazılı şekil öngörerek şekil serbestîsinin istisnası olan şekil zorunluluğu esasını da benimsemektedir (Oğuzman \& Öz 2013). Kanun koyucu bir kısım sözleşme türleri için yazılı şekil esası öngörürken, çoğu zaman işçiyi koruma amacı gütmek ve yazılı şeklin uyarma, bilgilendirme, açıklığa kavuşturma işlevlerini işçi yararına olarak kullanmayı hedeflemektedir. Yazılı şekil esasını kabul etmenin bir diğer amacı da iş sözleşmesine ilişkin uyuşmazlıklarda ispat kolaylığı sağlamasıdır. Zira işçi ile iş sözleşmesinden kaynaklanan pek çok uyuşmazlıkta yazılı belge ile ispat yükünü üzerinde taşıyan taraf çoğunlukla işverendir. İş akdinin kuruluşu gibi sona ermesi de prensip olarak herhangi bir şekle tâbi değildir. Tarafların sözleşmeyi sona erdirmeye yönelik açıklama veya davranışları ile de iş sözleşmesi sona erebilir (Oğuzman \& Öz 2013). Bunun yanında İş Hukukunun kısmen Kamu Hukukuna benzeyen kendine özgü yapısı işçiyi koruma amacı ve bu amaca hâkim olan ilkeleri göz önünde bulundurulduğunda şekil kurallarının da tıpkı Borçlar Hukuku'na tâbi diğer sözleşmelere uygulandığı gibi uygulanmasının ve nitelendirilmesinin mümkün olmadığ sonucuna varılmaktadır. Böylelikle, özellikle iş sözleşmeleri için öngörülen şeklin geçerlilik şartı ya da ispat şartı olarak nitelendirilmesi hususu sonuçları bakımından önemlidir. Çünkü şeklin geçerlilik şekli olarak belirlenmesi halinde şekil eksikliği tarafların iradesi hilafına sözleşmenin hükümsüzlüğü sonucunu doğurabilmektedir. Şeklin ispat şekli olarak öngörüldüğü hallerde ise şekil şartına uymamak sözleşmenin hükümsüzlüğü sonucunu doğurmadığı gibi şekil şartına uymamanın ispatı da bu durumda imkânsız olacaktır (Oğuzman \& Öz 2013; Oğuzman \& Barlas 2012; Kocayusufpaşaoğlu ve diğerleri, (2014); Eren, 2014; Altaş, 1998; Kilıçoğlu, 2012; Reisoğlu, 2012; Belen (2014); Tekinay ve diğerleri (2012); Antalya, 2012).

Tüm bu sebeplerle Türk Borçlar Kanunu'nun şekil esaslarını iş sözleşmeleri açısından ele almak, şekle ilişkin kuralları iş sözleşmesine has olarak yeniden nitelendirmek, şekil kurallarına aykırılığın müeyyidelerini ise Borçlar Hukuku'ndaki sözleşmenin geçersizliği müeyyidesinden bağımsızlaştırarak İş Hukuku'nun işçiyi koruma gayesine uygun bir şekilde tekrardan değerlendirmek gerekmektedir. Fakat belirtmek gerekir ki İş Hukuku'nun işçiyi koruma amacına uygun bir şekilde yeniden değerlendirmelerde İş Hukuku'na özgü sonuçların dayanağını da yine yürürlükteki Kanun hükümleri oluşturacaktır.

\section{2. İş Sözleşmesinin Kuruluşunda Şekil}

\subsection{Genel Kural Olan Șekil Serbestisi}

Sözleşmenin kurulması için gerekli olan irade beyanı değişik biçimlerde ve çeşitli araçlarla dışa vurulabilmektedir. İrade beyanının dışa vurulmasına yarayan araçlara ise şekil denilmektedir (Aybay, 1995). Şekil, yasa hükmü ile ya da taraf iradeleri ile belirlenen iradeyi açıklama şeklidir. Bir hukuki işlemin hüküm ve sonuç doğurabilmesi için bazı şekil kuralları öngörülüyorsa bu sisteme şekilcilik sistemi; böyle bir zorunluluk yoksa şekil serbestisi sistemi söz konusu olacaktır (Çelikbaş, 1987). TBK m. 12/1 hükmüne göre, sözleşmelerin geçerliliği Kanunda aksi öngörülmedikçe hiçbir şekle bağlı değildir. Bu maddeden anlaşılacağı üzere; Türk Hukukunda bir akdin kurulması için şekil serbestisi benimsenmiştir. Yasada bir akdin belli bir biçimde yapılmasına dair her hangi bir hüküm yoksa taraflar sözleşmeyi diledikleri şekilde yapabilir. Şekil serbestisi esas olarak şekilsizliği değil; şekil seçimindeki serbestlik durumunu belirtir. Taraflar, sözlü ya da yazılı şekilden birini tercih ederek seçim haklarını kullanırlar ve bu durum iradi şekil adını alır (Mollamahmutoğlu \& Astarlı, 2014). Şekil serbestisinin belirlenmediği durumların çeşitli faydaları olduğu gibi zararları da vardır. Şekil kuralının olması, tarafların bir sözleşmeyi imzalamadan önce düşünmelerini ve tedbirli hareket etmelerini sağlamakta; irade beyanlarına açıklık ve kesinlik getirmekte; ayrıca hukuki işlemlerin varlığı noktasında ispat bakımından kolaylıklar sağlamaktadır (Tekinay ve diğerleri, 1993). Ayrıca sözleşmede şekil zorunluluğu ilkesi sözleşmenin yerine getirilmesini zorlaştırabileceği gibi; ekonomik açıdan da sakıncalara neden olacaktır. Şekil şartının en önemli sakıncası ise sözleşmeyi samimi olarak yapmak isteyen kişilerin sadece şekil kuralına uymaması nedeniyle sözleşmenin geçersizliği ile karşı karşıya gelmeleridir (Eren, 2014). Kanun koyucu şekil serbestisini asıl saymakta; şekle bağlılığı ise belli işlem ve sözleşmeler için zorunlu kılmaktadır. İş sözleşmesi, rızai sözleşmelerdendir. Yukarıda şekle ilişkin belirtmiş olduğumuz hususlar çerçevesinde kural olarak iş sözleşmeleri hiçbir özel şart öngörülmeksizin, sadece karşılıklı irade beyanları ile kurulmaktadır. Ayrıca Borçlar Kanunu da iş sözleşmeleri için özel bir şekil öngörmemiştir.

\section{2. İstisna Olan Yazılı Şekil}

İş sözleşmesi her hangi bir şekle tâbi değilse de; Kanun hükmü ya da toplu iş sözleşmesi hükümleri ile istisnai olarak iş sözleşmesinin yazılı biçimde yapılması öngörülebilir. 4857 sayılı Kanunun yazılı şekli zorunlu gördüğü iş sözleşmeleri bakımından şekli bir geçerlilik koşulu olarak kabul etmek gerekir (Mollamahmutoğlu \& Astarlı, 2014). 4857 Sayılı İş Kanunu yazılı şekli zorunlu olarak öngörmediği durumda şekil şartının sadece iş sözleşmelerinde ispat şartı olarak düzenlendiği kabul edilir (Mollamahmutoğlu \& Astarlı, 2014). Bu durumda sözleşmenin sonuç doğurabilmesi için yasa belirli bir şekle uyulması mecburiyetini zorunlu tutmuş ise buna geçerlilik şekli denir. Sözleşme belirtilen şekle uygun olarak yapılmadıkça geçerli kabul edilemez. Ayrıca şekil şartı, bir iş sözleşmesinin geçerlilik koşulu olarak belirtilmiş ise, bu sözleşmenin hem objektif hem de sübjektif esaslı noktalarını kapsamalıdır (Eren, 2014). TBK m. 12/2'ye (BK m.11/2) göre de Kanunda öngörülen şekil, kural olarak geçerlilik şartıdır. İspat şartı olan şekil ise, Kanundan doğabileceği gibi taraf iradeleri ile de belirlenebilir. İspat şekli, geçerlilik şekli değildir. Zira ispat bakımından şekil Borçlar Kanununda düzenlenmiş bir husus da değildir. İspat şeklini bu açıdan geçerlilik şeklinden ayıran çizgi, ispat şekline uyulmaması durumunda sözleşmenin geçerli olarak kalacak olması; sadece söz konusu hakkın ispat edilemeyeceğidir (Tekinay 
ve diğerleri, 1993). Kanun koyucu bazı sözleşmelerin yapılmasını zorunlu olarak bir şekle tâbi kılmıştır. Örnek vermek gerekirse; arsa payı kat karşılığı inşaat sözleşmelerinde zorunlu olarak resmi şekil şartı aranmaktadır. Burada taraflar arsa payı karşılığı inşaat sözleşmesini resmi olarak noter vasıtasıyla yapabilirler. Buradaki amacın, sözleşmenin konusunun mahiyeti gereği taşınmaz olması ve bu durumun kamu tarafindan korunmasından dolayı, noter aracılığıyla düzenleme şeklinde sözleşmenin oluşturulması gerekmektedir. Aksi takdirde yapılan sözleşme sonuç doğurmaz. 4857 sayılı İş Kanunu m. 8/2 uyarınca; süresi bir yıl ve daha fazla olan iş sözleşmelerinin yazılı şekilde yapılması zorunludur. Dolayısıyla belirsiz süreli iş sözleşmeleri için Kanun koyucunun şekil serbestisini esas aldığı açıkça görülmektedir (Mollamahmutoğlu \& Astarl1, 2014). Birden çok işçinin meydana getirdiği bir takımı temsilen bu işçilerden birinin, takım kılavuzu sıfatıyla işverenle yaptığı sözleşmeye takım sözleşmesi denir (Çelik, 2013). Takım sözleşmesinin, oluşturulacak iş sözleşmelerinin yazılı yapılması gerekmektedir. Görüldüğü üzere Kanun bazı sözleşmelerin yazılı olarak yapılmasını açıkça öngörmektedir.

\section{3. Şekle Uymamanın Hüküm Ve Sonuçları}

\subsection{Geçerlilik şekli bakımından}

\subsubsection{Genel olarak}

TBK'nın 12. maddesinde, sözleşmelerin geçerliliğinin kanunda aksi öngörülmedikçe hiçbir şekil şartına bağlı bağlı olmadığı belirtilmiştir. Aynı madde de, kanunda sözleşmeler için belirtilen şekil şartının kural olarak geçerlilik şekli olduğu ve belirtilen şekle uyulmadan yapılan sözleşmelerin herhangi bir hüküm doğurmayacağı ifade edilmiştir.(Tuğ, 1994) Ayrica maddenin devamına göre ise kanunda öngörülen şekle uyulmadan yapılan sözleşmelerin hüküm doğurmayacağı belirtildiğinden bu şekle uyulmadan yapılan sözleşmelere, hükümsüzlük (geçersizlik) yaptırımı uygulanmaktadır (Eren, 2014; Tuğ, 1994) Şekil eksikliğinin ileri sürülmesi, hakkın kötüye kullanımını (TMK. m. 2/f. II) teşkil ettiği hallerde sözleşmenin şekil eksikliği yüzünden geçersizliği iddiaları dinlenmez ve bu durumda kurulan sözleşmeyi geçerli olarak kabul etmek gerekmektedir. TBK 12. maddesinde geçersizliğin türü bakımından herhangi bir düzenleme yapılmamıştır. Yargıtay yakın tarihli bir kararında taraflar arasında şekil eksikliği nedeniyle sözleşmenin geçersiz olduğuna belirtmiştir. Yargitay taraflar arasında kanuni şekil şartına uygun olarak yapılmayan, araç devrine ilişkin yapılan takas sözleşmesinin geçersiz olacağını belirtmiştir.

Bu durumdan anlaşılacağı üzere geçersiz olan sözleşmeler, tarafları açısından herhangi bir hak ve yükümlülük doğurmazlar. Bu nedenle, geçersiz bir sözleşmenin tarafları, o sözleşmeyle yükümlülüklerini yerine getirmekten kaçınabilirler. Fakat taraflara sadece aldıklarını karşı tarafa geri vermek yükümlülüğü getirir. Yargitay taraflar arasında sözleşme şekil eksikliği nedeniyle geçersiz olsa da, tarafların aldıklarını iade ile yükümlü olacaklarına dair çok sayıda kararıvardır Doktrinde TBK'nun 12. maddesinde sözleşmelerin kanunda öngörülen şekle uyulmaması durumunda geçersizliğin kesin hükümsüzlük olduğunu ifade eden görüş mevcut olmasına rağmen aynı zamanda doktrinde bu noktada butlan, kendine özgü geçersizlik, yokluk, iptal edilebilirlik ve kesin hükümsüzlük gibi farklı görüşler mevcuttur (Uygur, 2012; Kılıçoğlu, 2012).

\subsubsection{Yokluk Görüşü}

TBK m. 12'de belirtilen şekil şartına uyulmaması durumunda geçersizliğin kesin hükümsüzlük olduğunu ifade eden görüş yanında şekil şartına uyulmaması urumunda yokluk görüşünü savunan görüşler de mevcuttur. Roma Hukuku'nun ilk dönemlerinde bir işlemin hukuki sonuç doğurmasının sebebi irade beyan değil, iradenin ortaya çıktığı şekildir. Farklı bir anlatımla işlem öngörülmüş şekil kuralına uyulmuş ise geçerli olarak kabul edilmekte ancak öngörülmüş şekle uyulmadan sadece irade beyanları ile kurulan bir hukuki işlemin varlığından bahsetmek mümkün değildir (Kocayusufpaşa ve diğerleri, 2014; Eren, 2014; Oğuzman \& Öz 2013; Saymen \& Elbir, 1978 ). Ancak günümüzde hukuki işlemin kurulmasında esas olan şekil değil, irade beyanıdır. Çok sayıda hukuki işlem, hiçbir şekil şartı aranmaksızın, sadece irade beyanları ile kurulabilmekte ve hukuki sonuç doğurabilmektedir. Kanunun öngördüğü bir şekle uyulmadan yapılan hukuki işlem şekle uyulmasa dahi vardır, ancak hukuki sonuç doğurmamaktadır. Dolayısıyla bu durumdan anlaşılacağı üzere yokluk görüşü günümüzün modern hukuk sistemlerinde şekil anlayışı ile hiçbir şekilde bağdaşmamaktır. Daha net olarak ifade etmek gerekirse, bir hukuki işlem ancak kurucu unsurları bir araya gelmişse mevcut sayılır (Kocayusufpaşa ve diğerleri, 2014; Eren, 2014; Oğuzman \& Öz 2013; Saymen \& Elbir, 1978). Dolayısıyla TBK'nın 12. maddesinde belirtilen şekle uymayan sözleşmelerin hüküm doğurmayacağı ifadesi yokluk yaptırımını belirtmemektedir. TBK 12. maddede belirtilen yaptırım açıkça yokluk değil, geçersizlik olarak belirtilmiştir (Kocayusufpaşa ve diğerleri, 2014; Eren, 2014; Oğuzman \& Öz 2013; Saymen \& Elbir, 1978 ).

\subsection{3. İptal edilebilirlik görüşü}

Başlangıçtan itibaren geçerli olup hüküm ve sonuçlarını doğuran ancak iptal hakkı sahibi tarafından dilediği durumda sözleşmeyi geçmişe etkili olarak ortadan kaldırabilme durumunda iptal edilebilirlik söz konusu olur (Kocayusufpaşa ve diğerleri, 2014; Eren, 2014; Oğuzman \& Öz 2013; Saymen \& Elbir, 1978). İptal edilebilirlik şeklindeki hükümsüzlük için doktrinde farklı görüşler mevcuttur. Bu görüşlerden biri gerçek anlamı ile bir iptal hakk1 doğuran iptal edilebilirliktir (Kocayusufpaşa ve diğerleri, 2014; Tunçomağ, 1976) Gerçek anlamı ile bir iptal hakkı doğuran iptal edilebilirlik kavramı, iptal edilebilir olan sözleşmenin başlangıçta geçerli bir sözleşme gibi hüküm ve sonuçlarını doğurduğunu ancak iptal hakkının kullanılması ile sözleşmenin kesin hükümsüz hale geldiği sözleşmedir. Farklı bir anlatımla kendisine iptal hakkı tanınan taraf, bozucu yenilik doğuran hak niteliğindeki iptal hakkını kullandığı zaman hukuki işlem geçmişe etkili olarak, yapıldığı andan itibaren kesin hükümsüz hale gelmektedir (Kocayusufpaşa ve diğerleri, 2014; Eren, 2014; Oğuzman \& Öz 2013; Saymen \& Elbir, 1978).

$\mathrm{Bu}$ durumda, geçerli bir şekilde kurulmuş olan bir sözleşmenin hak sahibi tarafından geçmişe etkili olarak ortadan kaldırılabilmesine iptal denir (Eren, 2014; Oğuzman 
\& Öz, 2013). Buradan anlaşıldığı üzere sözleşme ancak iptal hakkının kullanılmasıyla sona ereceği için, iptal hakkı kullanılana kadar sözleşmenin geçerli olduğunu söylemek gerekir (Eren, 2014; Oğuzman \& Öz 2013). Burada önemli olan husus, kesin hükümsüz sözleșmelerden farklı olarak, iptal hakkı sahibi olan taraf iptal hakkını kullanmadıkça sözleşmenin hükümsüz olduğunu iddia edemezler (Kocayusufpaşa ve diğerleri, 2014; Eren, 2014; Oğuzman \& Öz 2013; Saymen \& Elbir, 1978). İptal, etkileri yönünden sadece sözleşmenin tarafları arasında hüküm ifade eder. Sözleşmenin tarafı olmayan kişiler iptal hakkını kullanamazlar (Eren, 2014).

Doktrinde savunulan ve bir diğer görüş olan gerçek olmayan anlamda iptal hakkı doğuran iptal edilebilirlik kavramına baktığımızda ise, buradaki iptal edilebilirlik kavramı sözleşmenin en baştan itibaren bir hüküm doğurmaması, söz konusu iptal hakkının kullanılması ile bu hükümsüzlüğün ortaya çıkacağını söylemek ile mümkün olur (Kocayusufpaşa ve diğerleri, 2014).

\subsubsection{Kendine Özgü Hükümsüzlük Görüşü}

TBK m. 12'de belirtilen şekil şartına uyulmaması durumunda geçersizliğin kesin hükümsüzlük olduğunu ifade eden görüş yanında şekil şartına uyulmaması durumunda kendine özgü hükümsüzlük görüşü görüşünü savunan görüşler de mevcuttur. Doktrinde yer alan görüşe göre, şekil eksikliğine butlan yaptırımının uygulanması yerinde değildir. Doktrindeki bu görüşe göre, bu durumda butlan değil, kendine özgü bir geçersizlik söz konusudur (Kılıçoğlu, 2011). Doktrinde yer alan bu görüşü savunanlar şekil eksikliğinin taraflar arasındaki bir geçersizlik olduğunu ve şekil eksikliğinin herkes tarafindan değil sadece taraflarca def'i olarak ileri sürülebileceğini belirtmektedirler(Kılıçoğlu, 2011). Kesin hükümsüzlükte ise, hukuki işlemin bütün kurucu unsurları tamamdır. Ancak hukuk düzeninin istediği bir geçerlilik şartı eksiktir. Farklı bir anlatımla hukuki işlemin daha doğumunda bir sakatlık mevcuttur. Bu eksikliklerden biri de TBK m. 12 ile getirilen şekil şartına uyulmamış olmasıdır (Kocayusufpaşa ve diğerleri, 2014; Eren, 2014; Oğuzman \& Öz 2013; Saymen \& Elbir, 1978). Şekil eksikliği nedeniyle geçersiz olan sözleşme en başından itibaren hiçbir hüküm ve sonuç doğurmaz (Kocayusufpaşa ve diğerleri, 2014; Eren, 2014; Oğuzman \& Öz, 2013). Yargılama esnasında Hakim düzeltilmesi mümkün olmayan şekil eksikliğini dosyada gördüğü zaman yargılamanın her safhasında taraflar ileri sürmese bile kendiliğinden göz önüne almak zorundadır. Dolayısıyla şekil eksikliği tarafların onayı ve rızası ile geçerli hale gelmez. Hatta tek tarafa borç yükleyen sözleşmelerde borçlanılan edim ifa edilmişse dahi, bu ifa geçerli bir sebebe dayanmadığ 1 için sebepsiz zenginleşme hükümlerine istinaden verilen şey geri istenebilir (Eren, 2014).

\subsection{5. Şekil Eksikliğiyle Sakat Sözleşmenin Başka Bir Hukuki Işsleme Dönüşmesi}

Hukuk düzeninde aynı ya da benzer bir amaca ulaşmaya yönelik çeşitli hukuki işlemler vardır. Şekil eksikliği nedeniyle geçersiz bir hukuki işlemin yerine, bu hukuki işlemin gerçekleştirmek istediği amacı başka bir hukuki işlem ile yapılabilecek ise ve söz konusu şekil için bu işlem için yeterliyse, sözleşmenin taraflarının iradeleri de bu yönde ise, batıl işlem geçerli işlem yerine geçer (Narmanlıoğlu, 2014; Süzek, 2016;Tekil, 1981; Mollamahmutoğlu / Astarlı / Baysal, 2014; Tunçomağ / Centel, 2013; Centel / Demircioğlu, 2015; Reisoğlu, 1968; Zevkliler / Gökyayla, 2013; Kılıçoğlu / Şenocak, 2013; Zevkliler, 2004). Hukuk düzeninde bu işleme çevirme ya da tahvil denir. Tahvile tarafların uyguladıkları şekil şartının yapmak istedikleri sözleşme için kanunda belirtilen resmi şekil şartını içermemekle birlikte, aynı sonuca ulaşmak için başka bir işlem öngörülen yazılı şekil şartını içermesi halinde, tahvile uygun olması gösterilir (Eren, 2014; Oğuzman \& Öz, 2013). Yargılama sırasında Hakim tarafların iradelerinin istenilen işlemin şekil eksikliği nedeniyle sonuç doğurmaması halinde diğer işlemi yapma yönünde olduğu sonucuna kanaat getirirse tahvile karar verir (Eren, 2014). Tahvil için doktrinde üç unsurun bulunmasının gerektiği öngörülmüştür (Oğuzman \& Öz, 2013). Bu unsurlar, ortada kesin hükümsüz bir sözleşmenin bulunması, bu sözleşmenin çevrileceği sözleşmenin maddi ve şekli bütün unsurları içeriyor olması ve tarafların sözleşmenin kesin hükümsüz olduğunu bilmeleri halinde tahvil ile geçerli sayılacak sözleşmeyi yapacaklarını kabul etmesidir (Oğuzman \& Öz, 2013; Kaneti, 1972)

\section{2. İspat Şekli Bakımından}

Usul Hukuku'nda şekil kurallarının uygulama alanı, maddi hukuka göre farklıdır. Usul Hukuku'nda şekle aykırılık durumunda maddi hukukta olduğu gibi her zaman butlan yaptırımı uygulanmaz (Pekcanıtez ve diğerleri, 2013). Hukuk Muhakemeleri Kanunu'nda hangi işlemin kamu düzenine aykırı olduğu hususunda herhangi bir açıklık bulunmamaktadır. Genel olarak kamu düzeni, ülkede kamu hizmetlerinin iyi bir şekilde yapılması, devletin güvenliğini, düzenini ve kişiler arasındaki ilişkilerde hukuku ve ahlak kurallarına uygunluğu sağlamaya yarayan kuralların tümü, toplumun huzur ve sükûnunun sağlanmasını, devletin ve devlet yapısının korunmasını hedef tutan, toplumun her alanındaki düzeninin temelini oluşturan kurallar şeklinde tanımlanabilir (Sözen, 1992). Doktrinde Medeni Usul Hukuku'nda kamu düzenine ilişkin bütün kurallar için, talepte bulunanları düşünmeye, dikkatli davranmaya sevk eden hükümler kamu düzeninden sayılır denilmektedir (Karsl1, 2012). Ayrıca taraflara yargılama sirasında farklı imkanlar tanınması, davanın gereksiz yere uzatılması ve hakkın kötüye kullanılması gibi durumlar kamu düzenini ilgilendiren hususlardır. Bu nedenle sslah (HMK m. 176/2) veya ikinci tanık listesinin verilememesi (HMK m. 240/2) gibi işlemlerin dava sırasında bir kez yapılabilmesi gibi hükümler hakkın kötüye kullanılmasını ve davanın gereksiz yere uzatılmasını önlemek düşüncesiyle düzenlenmiştir (Pekcanıtez ve diğerleri , 2013) Zira bir davanın gereksiz yere uzaması, sadece davanın taraflarını değil, çoğu kez kamuyu da ilgilendirmektedir. Çünkü bir davanın gereksiz bir şekilde uzaması sebebiyle mahkemenin iş yükü artacağından, bu durum, diğer davaların da uzamasına sebebiyet verecektir.

Bunun gibi, dava dilekçesinin davalıya tebliğ edilmeden ve yargılama sırasında taraflara bilirkişi raporları tebliğ edilmeden ve tarafların itirazları dikkate alınmadan dava hakkında hüküm kurmak da kamu düzenine aykırılık durumu oluşur (Pekcanıtez ve diğerleri , 2013). Ayrıca bazı kamu 
düzenine ilişkin kurallar, tarafların söz konusu usul işlemini yapmadan önce düşünmesine ve daha dikkatli davranmasına yöneliktir. Ayrıca dava dilekçesinde bulunması zorunlu olan davacı ile davalının adı, soyadı ve adresleri (HMK m. 119/1b), davacının Türkiye Cumhuriyeti kimlik numarası (HMK m. 119/1-c), varsa tarafların kanuni temsilcilerinin ve davacı vekilinin adı, soyadı ve adresleri (HMK m. 119/1-ç), açık bir

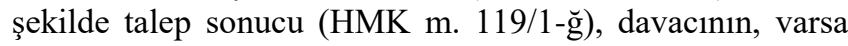
kanuni temsilcisinin veya vekilinin imzası (HMK m. 119/1h) da kamu düzenine ilişkindir. Hukuk Muhakemeleri Kanununda eğer işlem kamu düzenine aykırı ise, bunu mahkeme kendiliğinden dikkate alır. Zira kamu düzenine aykırılık diğer tarafın ileri sürmesine gerek olmaksızın kendiliğinden göz önünde tutulur (Pekcanıtez ve diğerleri , 2013).

Usul işlemlerindeki şekil eksikliği her zaman kamu düzenine ilişkin değildir. Usuli işlemlerdeki eksiklik giderilebilir ya da düzeltilebilir nitelikte ise bu eksiklik karşı tarafça ileri sürüldüğünde, işlem geçersiz sayılmaz, sadece işlemde bulunan eksiklik düzeltilir (Karsl1, 2012). Bu düzeltme işlemi ise hatalı işlemin doğrusunun yapılması, geçmişe etkili şekilde icazet verilmesi ve ya itiraz etme hakkının kullanılmaması şeklinde söz konusu olabilir. Fakat bu işlemler kamu düzenine ilişkin olması durumunda bunların düzeltilmesi mümkün olmaz. TBK'nın 12. maddesinde, sözleşmelerin geçerliliğinin kanunda aksi öngörülmedikçe hiçbir şekil şartına bağlı bağlı olmadığı belirtilmiștir. Aynı madde de, kanunda sözleşmeler için belirtilen şekil şartının kural olarak geçerlilik şekli olduğu ve belirtilen şekle uyulmadan yapılan sözleşmelerin herhangi bir hüküm doğurmayacağı ifade edilmiştir.(Tuğ, 1994)

\section{Sonuç ve Öneriler}

Hukuk sistemimizde yer alan iş sözleşmesinin şekline ilişkin düzenlemeler temelini Türk Borçlar Kanunu'ndan almaktadır. Kanun koyucu şekil kuralları açısından Türk Borçlar Hukukunun genel esaslarının dışına çıkmamıştır(Arslan Ertürk, 2017)

İş Hukukunun işçiyi koruma amacının bir sonucu olarak şekil kurallarına aykırılığı İş Hukuku bağlamında kendine özgü yaptırımlara bağlamak gerekmektedir. Çünkü Türk Borçlar Hukukunda öngörülen şekil kurallarına uyulmamasının yaptırımı geçersizliktir. İş Hukukunun işçiyi koruma amacı göz önüne alındığında geçersizlik işçi için ağır bir sonuçtur(Arslan Ertürk, 2017) Şekil şartı bakımından iş sözleşmesinin yapılmasının zorunlu olduğu durumlarda Kanun koyucu işçiyi koruma dürtüsüyle hareket etmektedir. Diğer hallerde işçinin sözleşme olmadan çalıştırılması ve haklarını tam olarak talep edememesi ortaya çıkabilecektir. Kanun koyucunun işveren bakımından sözleşme yapılmasını zorlayıcı veya zorunlu kılan hükümler koymasının sebebi de işçinin korunması amacıdır. İşçiler İş Kanunu bakımından haklarını koruyabilmelidirler. $\mathrm{Bu}$ ağır sonucu gidermek için iş sözleşmeleri açısından şekil kurallarını genellikle ispat şekli olarak değerlendirmek gerekir. Yazılı şeklin geçerlilik şekli olarak kabul edildiği durumlarda şekle aykırılığın geçersizlik yaptırımına bağlamaktan ziyade mümkün olduğu ölçüde sözleşmeyi ayakta tutma amaçlanmalıdır. İş Kanununda aksi belirtilmedikçe iş sözleşmesinin kurulması özel bir şekle tâbi değildir. Yine Türk Borçlar Kanununda aksine bir düzenleme söz konusu değilse, hizmet sözleşmesinin kurulması için de herhangi bir şekil şartı öngörülmemiştir. Kanun koyucu iş sözleşmelerinin kuruluşunda genel kural olan şekil serbestisi esasını kabul etmekle birlikte sözleşmenin yazılı şekilde yapılmaması durumunda işvereni işçiye genel ve özel çalışma koşullarını gösteren yazılı bir belge verme yükümlülüğü yüklemiştir(Arslan Ertürk, 2017).

İş sözleşmelerinin kuruluşunda genel olarak şekil serbestisi ilkesi kabul edilmiş ise de bazı sözleşme türlerinde yazılı şekil zorunluluğu da öngörülmüştür. Örneğin, takım sözleşmesi ve Özel Eğitim Kurumları Kanununda iş sözleşmesinin yazılı olarak yapılması gerekir(Arslan Ertürk, 2017)

İş Kanunu genel çerçevesiyle işçiyi koruyucu hükümleri içermektedir. Bu yönüyle bakıldığında TBK'daki geçersizlik yaptırımı hukuka uygun olsa da İş Kanunu bakımından da Kanunun amacına aykırı durumdadır. $\mathrm{Bu}$ aykırı durumu yumuşatma adına şekil şartına ilişkin yaptırımın geçersizlik olmaması, şekil şartının ispat aracı olarak değerlendirilmesi gerekmektedir. Sözleşme yapma niyet ve iradesinin varlığının esas kabul edilerek sözleşmenin ayakta tutulmaya çalışılması amaçlanmalıdır.

Tüm bu gerekçelerle iş sözleşmelerinin yazılı şekilde yapılması işçi lehine bir durum olarak kabul edilir. Yazılı yapılacak iş sözleşmeleri ile işçiler haklarını sözleşme ile de güvence altına alabilecek ve çalışma koşullarını açık bir şekilde öğrenebilecek ve haklarını daha kolay bir şekilde arayabilecektir

\section{Kaynakça}

Altaş, H. (1998). Şekle Aykırılığın Olumsuz Sonuçlarının Düzeltilmesi, Ankara.

Antalya, G. (2012). Borçlar Hukuku Genel Hükümler, İstanbul, Beta Basım Yayın.

Arslan Ertürk, A. (2017). İş Sözleşmesinde Şekil, Vedat Kitapçılık, İstanbul.

Centel, T., \& Demircioğlu, A.M. (2015). İş Hukuku. 18. Bas1, İstanbul.

Çelikbaş, D. (1987). "Şekle Aykırılık Ve Şekle Aykırılığı İleri Sürmenin Sınırı Olarak Hakkın Kötüye Kullanılması Yasağı", Prof. Dr. Kudret Ayıter'e Armağan, Ankara.

Eren, F,(2012).Borçlar Hukuku Genel Hükümler, 14. Bası, Ankara.

Eren, F.(2014): 6098 Sayılı Türk Borçlar Kanununa Göre Hazırlanmış Borçlar Hukuku Genel Hükümler, 16. Bask1, Ankara.

Hatemi, H., \& Serozan, R. ,(1993) Aile Hukuku, İstanbul.

Helvacı, S., \& Erlüle, F. (2010). Medeni Hukuk, İstanbul.

İnan, A.N., \& Yücel, Ö.(2014). İnan Borçlar Hukuku Genel Hükümler, 4. Bası, Ankara.

Kaneti, S.(1972). Hukuki İşlemlerin Çevrilmesi, İstanbul.

Karslı, A. (2012). Medeni Muhakeme Hukuku, İstanbul (Anılış: Medeni Muhakeme).

Kılıçoğlu, A. (2011). Borçlar Hukuku Genel Hükümler 
(Yeni Borçlar Kanununa Göre Hazırlanmış) 14. Bası, Ankara. (Anılış: Borçlar)

Kılıçoğlu, A. M. (2012). Borçlar Hukuku Genel Hükümler, 16. Bas1, Ankara.

Kılıçoğlu, Mustafa / Şenocak, Kemal: İş Kanunu Şerhi. 3. Bask1, İstanbul 2013.

Kocayusufpaşa,N.,Hatemi H.,Serozan, R., \& Arpac1, A.(2014) Borçlar Hukuku Genel Bölüm, Borçlar Hukukuna Giriş -Hukuki İşlem -Sözleşme, İstanbul.

Kocayusufpaşaoğlu, N., Hatemi, H., Serozan, R., \& Arpacı, A. (2008) Borçlar Hukuku Genel Bölüm, İstanbul.

Mollamahmutoğlu , H., Astarlı, M., \& Baysal, U. (2014). İş Hukuku, Gözden Geçirilmiş Ve Genişletilmiş 6. Bası, Ankara.

Narmanlıŏlu, Ü. (2014). İş Hukuku Ferdi İş İlişkileri I, 5.B., İstanbul.

Oğuzman, K., \& Öz, T. (2013) Borçlar Hukuku Genel Hükümler C. I, B. 11, İstanbul (Anılış: Borçlar).

Oğuzman, M. K., \& Barlas, N. (2012). Medeni Hukuk, 18. Bası, İstanbul, Vedat Kitapçılık.

Pekcanıtez, H., Atalay, O., \& Özekes, M. (2013). Medeni Usul Hukuku, Ankara.
Pekcanitez, H., Atalay, O., Sungurtekin Özkan, M., \& Özekes, M.(2013) İcra Ve İflas Hukuku, Ankara.

Reisoğlu, S.(2012). Borçlar Hukuku Genel Hükümler, 7. Bas1, İstanbul.

Saymen, F.H., \& Elbir, H.K(1978). Türk Borçlar Hukuku, İstanbul.

Süzek, S. (2016). İş Hukuku, Yenilenmiş 12. Baskı, İstanbul.

Tekil, F.(1981). İş Hukuku. İstanbul.

Tekinay, S. S., Akman, S.,Burcuoğlu, H., \& Altop, A.(1993) Tekinay Borçlar Hukuku Genel Hükümler, Yeniden Gözden Geçirilmiş Ve Genişletilmiş Yedinci Baskı, İstanbul.

Tuğ, A.(1994). Türk Özel Hukukunda Şekil, Konya.

Tunçomağ, K. (1968). Borçlar Hukuku Genel Hükümler, C. 1, 3. Bas1, İstanbul.

Uygur, T. (2012) Türk Borçlar Kanunu Şerhi, İstanbul.

Zevkliler, A. (2004) Borçlar Hukuku Özel Borç İlişkileri, Ankara.

Zevkliler, A., \& Gökyayla, K.E. (2013). Borçlar Hukuku Özel Borç İlişkileri, İstanbul. 